\title{
Postmortem Health and Pollution Investigations on Harbor Seals (Phoca vitulina) of the Islands Helgoland and Sylt
}

\author{
Antje Kakuschke, ${ }^{1}$ Juergen Gandrass, ${ }^{1}$ O. P. Luzardo, ${ }^{2}$ L. D. Boada, ${ }^{2}$ \\ Annalisa Zaccaroni, ${ }^{3}$ Simone Griesel, ${ }^{1}$ Mechthild Grebe, ${ }^{1}$ Daniel Pröfrock, ${ }^{1}$ Hans-Burkhard \\ Erbsloeh, ${ }^{1}$ Elizabeth Valentine-Thon, ${ }^{4}$ Andreas Prange, ${ }^{1}$ and Katharina Kramer ${ }^{1}$
}

\author{
${ }^{1}$ Marine Bioanalytical Chemistry, Institute of Coastal Research, Helmholtz Centre Geesthacht, 21502 Geesthacht, Germany \\ ${ }^{2}$ Department of Clinical Sciences and Instituto Canario de Investigación del Cáncer, University of Las Palmas de Gran Canaria, \\ 35080 Las Palmas de Gran Canaria, Spain \\ ${ }^{3}$ Department Veterinary Medical Sciences, University of Bologna, 47042 Cesenatico, Italy \\ ${ }^{4}$ Immunology Department, Health Diagnostics and Research Institute, South Amboy, NJ 08879, USA
}

Correspondence should be addressed to Antje Kakuschke, antjekakuschke@web.de

Received 19 November 2011; Accepted 20 December 2011

Academic Editors: A. Arslan, S. P. Lambeth, and C. P. Wheater

Copyright (๑) 2012 Antje Kakuschke et al. This is an open access article distributed under the Creative Commons Attribution License, which permits unrestricted use, distribution, and reproduction in any medium, provided the original work is properly cited.

\begin{abstract}
Helgoland and Sylt are important centers of tourism in the North Sea. Harbor and grey seals are one reason for the attraction of these islands. However, little is known about these local seal groups. The present postmortem health and pollution study describes a multiparameter investigation of five ill harbor seals which were shot for animal welfare reasons. Firstly, results of pathology and blood investigations support the bad prognosis of survival made in the field. Signs of inflammation in organs, malnutrition, a high-stress level, and reduced thyroid activity were found. Secondly, metal and organic contaminants were investigated. Metal pollutants in blood, liver, muscle, and kidney tissue were not elevated. Lead and mercury concentrations showed a decreased level compared to former studies. Additionally, interesting insights were found for several organic contaminants in comparison with other studies. The Helgoland seals may be influenced by the contaminants of the Elbe plume.
\end{abstract}

\section{Introduction}

The ongoing and increasing use of the North Sea and its unique Wadden Sea areas for fishing, offshore wind parks, and as dumping site for dredged material containing various pollutants represents the main anthropogenic threat to this ecosystem. Besides determining contamination levels of selected environmental compartments such as sediments or the related water column, measuring body burdens of marine animals remains a widely established environmental assessment strategy [1-7]. In this context, marine mammals such as harbor seals (Phoca vitulina) are accepted indicators, in particular for medium and long-term ecosystem changes, due to their long lifespan and their role as top predators within the marine food web [8]. Correlations between bioaccumulation of environmental contaminants in the tissues of marine mammals and immunosuppressive effects enhancing the animals' vulnerability to infectious diseases or pathogens have been described [9-11].

The tissue of seals found dead occasionally along the Wadden Sea coast line represents an important sample material which could be used for pathological investigations and for estimating contaminant body burdens in monitoring programs. However, to describe complex parameters such as the individual health status of marine mammals, an informative set of investigations has to be performed. Recently, we described a study including metals, organic contaminants, selected marker proteins as well as a number of immunological and clinical chemistry parameters to assess the health status of individual marine mammals based on blood samples [12].

Within the framework of the Trilateral Monitoring and Assessment Program (TMAP), German marine mammal monitoring activities include aerial surveys and counting of 
living and dead seals providing valuable information related to the development of the population size $[13,14]$. Abt and Engler considered the grey seal (Halichoerus grypus) pup production at Helgoland [15]. Within the project MINOS, Adelung and Müller investigated the diving behavior and animal tracks of harbor seals of the Wadden Sea including Helgoland [16].

The health monitoring focuses on pathological investigations of dead seals found along the Schleswig-Holstein Wadden Sea coast [17] and blood sample investigations of living seals from the sand bank Lorenzenplate [18]. Although these activities include seals from the islands Sylt and Helgoland, the locations are not considered separately, and little is known about the local groups of these islands. In a previous study, we published data on the health parameter haptoglobin measured in plasma of seals (Phoca vitulina) from Helgoland [19].

To establish new diagnostic parameters or to conduct in vitro experiments to understand the effects of contaminants on a molecular level, which will provide a deeper insight into the health status of such natural populations, the available sample types as well as their quality and quantity are of great importance. The seals used in the present study had to be shot due to severe illness. Using a helicopter transport, the time between death and necropsy was shortened, which helped to maintain the integrity of the samples and to collect sufficient sample amounts for new methodological developments and approaches such as proteomics or in vitro liver cell culture assays [20-24]. The present study provides, for the first time, a basic data set of multiple health parameters and contaminant body burdens of animals from these areas.

\section{Materials and Methods}

2.1. Animals. Five severely ill harbor seals (Phoca vitulina) were found by seal rangers on Helgoland (four animals) and Sylt (one animal), both islands of the German North Sea (Table 1, Figure 1). The animals were shot for animal welfare reasons by an official seal ranger who is obliged to follow a standard protocol and is permitted to kill a seal only if certain clinical criteria are fulfilled. Immediately after death, blood was collected into monovettes after puncture of the epidural vertebral vein using a $20 \mathrm{~mL}$ syringe and a $1.2 \mathrm{~mm} \times 100 \mathrm{~mm}$ needle (TSK-Supra, TSK Laboratory, Japan). The tubes were carefully agitated and kept at room temperature until further sample processing. Blood samples were collected in serum, in EDTA and in lithium heparin monovettes for metal analysis (all Sarstedt AG \& Co, Nümbrecht, Germany). Furthermore length, weight, and sex were assessed. Age was estimated based on length and weight. All animals were juveniles (<one-year old).

After completing the first investigations and blood drawing in the field, the animals were transferred in a transportation box by a helicopter (helicopter type MBB BO 105, Helicopter Service Wasserthal GmbH, Hamburg, Germany) to the dissecting room of the Research and Technology Centre (FTZ) in Büsum, Germany, for necropsy
TABLe 1: Details of harbor seals of the islands Helgoland and Sylt investigated in this study.

\begin{tabular}{lcccccc}
\hline $\begin{array}{l}\text { Seal } \\
\text { code }\end{array}$ & $\begin{array}{c}\text { Date of } \\
\text { sampling }\end{array}$ & Sex & $\begin{array}{c}\text { Age } \\
\text { (year) }\end{array}$ & Location & $\begin{array}{c}\text { Length } \\
(\mathrm{cm})\end{array}$ & $\begin{array}{c}\text { Weight } \\
(\mathrm{kg})\end{array}$ \\
\hline Pv 01 & 5.12 .07 & Female & $<1$ & Helgoland & 101 & 17.8 \\
Pv 02 & 5.12 .07 & Male & $<1$ & Helgoland & 110 & 17.4 \\
Pv 03 & 29.1 .08 & Female & $<1$ & Helgoland & 97 & 15.8 \\
Pv 04 & 29.1 .08 & Male & $<1$ & Helgoland & 112 & 22.6 \\
Pv 05 & 14.2 .08 & Male & $<1$ & Sylt & 100 & 17.4 \\
\hline
\end{tabular}

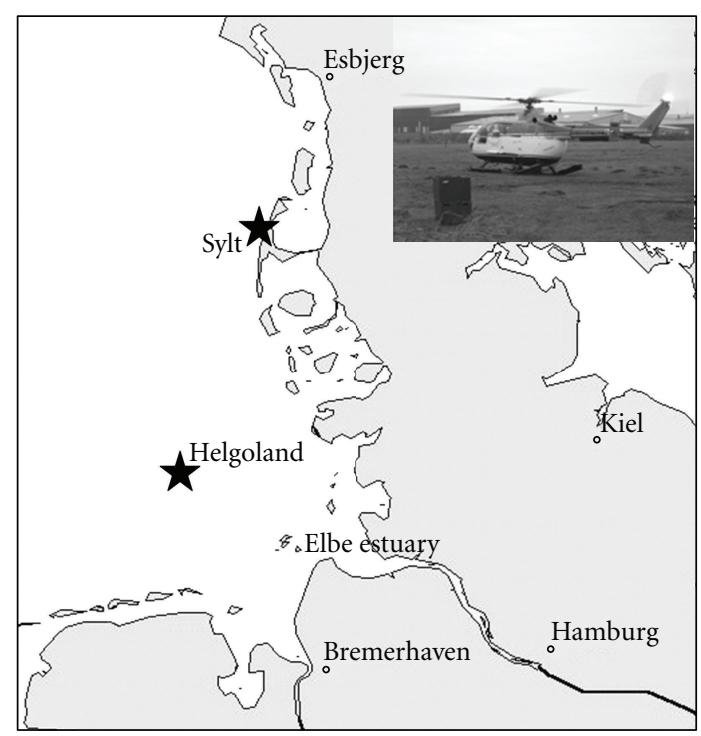

FIgURE 1: The seals were sampled on the islands Helgoland and Sylt, Germany.

examinations. Due to the rapid transportation (approximately 1 hour), very fresh tissue sample material could be obtained for necropsy and further research studies, for example, cultivation of liver cells [24].

Blood samples were transported immediately to the respective laboratories or to the Helmholtz-Zentrum (HZG), Geesthacht, Germany, for further sample processing or storage at $-80^{\circ} \mathrm{C}$. Plasma samples were taken, frozen and sub-samples sent to the respective laboratories in Spain and Italy for the analysis of organic contaminants and thyroid hormones.

2.2. Pathology. Necropsy was performed as soon as an animal arrived at the FTZ Büsum, about one hour after death. Body condition and macroscopically findings were evaluated. The necropsy involved the investigation of intestine, stomach, liver, spleen, lung, and thymus. Samples from liver, kidney, and muscle tissue were collected. Sub-samples were taken and frozen, and sent to the respective laboratory in Italy for metal analysis.

2.3. Health Parameters in Blood Samples. For the diagnosis of inflammatory conditions in the body, serum electrophoresis 
and measurements of several acute phase proteins were performed. Total protein, albumin, and globulin level were investigated after standardized protocols using electrophoresis with an automated analyzer (Olympus Hite 320, Olympus Deutschland GmbH, Hamburg, Germany) at the Synlab.vet Hamburg, Germany. Further, the following acute phase proteins were measured: C-reactive protein (CRP), haptoglobin (Hp), transferrin (Tf), and carbohydrate deficient transferrin (CDT). Concentration of CRP in serum samples was analyzed at the Synlab.vet Hamburg using turbidometry (Olympus AU 2700, Olympus Deutschland GmbH). The measurement of $\mathrm{Hp}$ in serum was performed at the HZG using a multispecies Hp assay from Tridelta Development Limited (Maynooth, Kildare, Ireland). The quantification of $\mathrm{Tf}$ and $\mathrm{CDT}$ was conducted in serum samples as described in former studies at the HZG [20, 22].

Additionally, several enzymes and hormones were analyzed to investigate organ functions and body condition. The enzyme activities of alkaline phosphatase (AP), aspartate aminotransferase (AST), alanine aminotransferase (ALT), gamma-glutamyl transferase $(\gamma$-GT), cholinesterase, lactate dehydrogenase (LDH), alpha-amylase, lipase, creatine kinase (CK) as well as the amount of total bilirubin, cholesterol, triglyceride, creatinine, bile acid, urea, and glucose were analyzed using photometry (Olympus AU 2700, Olympus Deutschland GmbH). Cortisol was analyzed using a chemiluminescence immunoassay (CLIA, Immulite 2000, Siemens AG, Erlangen, Germany). All investigations were performed in serum samples at the Synlab.vet Hamburg with standardized methods. The thyroid hormones thyroxine (T4) and triiodothyronine (T3) were analyzed in serum samples using RIA commercial kits (Chematil, Angri, Italy) and the radioactivity counted using a Packard 1600 TR $\beta$-counter at the University of Bologna, Italy.

2.4. Element Analysis of Whole Blood and Plasma. The element analysis was performed for whole blood and plasma. For whole blood samples the sample preparation and multielement determination were done according to the procedure described in former studies [3]. For plasma analysis, the whole blood was centrifuged ( $3000 \mathrm{~g}$, Centrifuge 5804G, Eppendorf AG), diluted $(1+9)$ by MilliQ water, and filtered $(<0.2 \mu \mathrm{m}$, Nylon ProFillTMPlus, MedChrom $\mathrm{GmbH}$, Flörsheim-Dalsheim, Germany). Twenty elements were analyzed in whole blood and plasma. $\mathrm{Al}, \mathrm{Be}, \mathrm{Cd}$, $\mathrm{Co}, \mathrm{Cr}, \mathrm{Mg}, \mathrm{Mn}, \mathrm{Mo}, \mathrm{Ni}, \mathrm{Pb}$, and $\mathrm{V}$ were analyzed using an ICP-MS with a collision cell (Agilent 7500c ICP-MS, Agilent Technologies). Measurements of $\mathrm{As}, \mathrm{Ca}, \mathrm{Cu}, \mathrm{Fe}$, $\mathrm{K}, \mathrm{Rb}, \mathrm{Se}, \mathrm{Sr}$, and $\mathrm{Zn}$ were performed by total $\mathrm{X}$-rayfluorescence spectrometry (TXRF) (Atomika TXRF 8030 C, FEI Company, Oberschleissheim, Germany).

2.5. Metal Hypersensitivities. Metal-specific lymphocyte proliferation was investigated using a lymphocyte transformation test (LTT). The special modification, MELISA (Memory Lymphocyte Immunostimulation Assay), was performed as previously described in the Laboratory Center Bremen,
Germany [25-27]. The mitogen- and nonstimulated lymphocyte proliferation was tested as well as the metalspecific proliferation after stimulation with the following metals/metal species: $\mathrm{Al}, \mathrm{Au}, \mathrm{Be}, \mathrm{Cd}, \mathrm{Cr}, \mathrm{Cu}$, ethylmercury (EtHg), mercurychloride $(\mathrm{HgCl})$, methylmercury $(\mathrm{MeHg})$, phenylmercury $(\mathrm{PhHg}), \mathrm{Mo}, \mathrm{Ni}, \mathrm{Pb}, \mathrm{Sn}$, and $\mathrm{Ti}$. The stimulation index (SI) was calculated as follows: $\mathrm{SI}=$ metalstimulated proliferation ( $\mathrm{cpm}$ )/non-stimulated proliferation (cpm).

SI $>3$ was regarded as a positive hypersensitivity response.

SI 2-3 is interpreted as a possible sensibilisation.

SI $<0.1$ is interpreted as a suppressive effect.

In this study, the test was performed for three of five animals (Pv 01, 02, 05).

2.6. Metal Analysis of Liver, Kidney, and Muscle Tissue. Selected toxic elements were analyzed in liver, kidney, and muscle tissues at the University of Bologna, Italy. Subsamples $(0.7 \mathrm{~g})$ of each tissue were digested with a Milestone MLS 1200 mega microwave oven using $4 \mathrm{~mL}$ nitric acid and $1 \mathrm{~mL}$ hydrogen peroxide. Measurements of $\mathrm{As}, \mathrm{Hg}, \mathrm{Pb}$, and Cd were performed by inductively coupled plasma optical emission spectrometry (ICP-OES) using a Perkin Elmer Optima 2100 DV instrument, coupled with a CETAC U5000AT+ ultrasound nebulizer for Hg. Two blanks were run during each set of analysis to check for the purity of the chemicals. The accuracy of the method was verified with a reference material (CRM 278: lyophilized mussel, Community Bureau of Reference, BCR, Brussels). All values of the reference material were within certified limits.

2.7. Chlorinated Pesticides and PCBs in Plasma. Aliquots of plasma were subjected to solid-phase extraction (SPE) and analyzed by gas chromatography-mass spectrometry (GCMS) following the procedure described in our previous study [12]. The measurements were performed at the University of Las Palmas de Gran Canaria, Spain. 17 chlorinated pesticides and metabolites as well as 27 polychlorinated biphenyl congeners (PCBs) were included in this study. Limits of quantification (LOQs) were determined from 10fold standard deviations of blanks. LOQs were $50 \mathrm{ng} \mathrm{L}^{-1}$ for methoxychlor and DDT including metabolites, and $10 \mathrm{ng} \mathrm{L}^{-1}$ for the rest of the analytes.

\section{Results and Discussion}

3.1. Pathology. All five harbor seals showed comparable pathologic findings; for example, they showed signs of acute catarrhal enteritis including swollen mesenteric lymph nodes. In three animals ( $\mathrm{Pv}$ 03-05), single Acanthocephala spp. were found in the small intestine. In four animals ( $\mathrm{Pv} 01$, 03-05), nematodes were found in the stomach. The liver of all five seals showed multifocal small white partly confluent foci of 1 to $4 \mathrm{~mm}$ in diameter. In three animals ( $\mathrm{Pv}$ 0204 ), the spleen was pulpous hyperplasic. Additionally, all five 
TABLE 2: Element profile in whole blood (WB) and plasma $(\mathrm{P})\left[\mu \mathrm{g} \mathrm{L}^{-1}\right]$ samples of seals investigated in this study compared to our previous study on seals of the German Bight [3].

\begin{tabular}{|c|c|c|c|c|c|c|c|}
\hline & & Pv 01 & Pv 02 & Pv 03 & Pv 04 & Pv 05 & $\begin{array}{l}\text { Phoca vitulina } \\
\text { German Bight }\end{array}$ \\
\hline \multirow{2}{*}{$\mathrm{Al}$} & WB & 1.17 & 1.72 & 1.32 & 0.80 & - & \multirow{2}{*}{$<0.17-499$} \\
\hline & $\mathrm{P}$ & - & 8.43 & - & - & 2.81 & \\
\hline \multirow{2}{*}{ As } & WB & 287 & 449 & 290 & 732 & - & \multirow{2}{*}{$42.0-592$} \\
\hline & $\mathrm{P}$ & 130 & 1010 & 478 & 1940 & 285 & \\
\hline \multirow{2}{*}{$\mathrm{Be}$} & WB & $<0.08$ & $<0.08$ & $<0.08$ & $<0.08$ & - & \multirow{2}{*}{$<0.08-1.80$} \\
\hline & $\mathrm{P}$ & $<0.08$ & $<0.08$ & $<0.08$ & $<0.08$ & $<0.08$ & \\
\hline \multirow{2}{*}{$\mathrm{Ca}$} & WB & $45.8 * 10^{3}$ & $59.2 * 10^{3}$ & $70.2 * 10^{3}$ & $53.7 * 10^{3}$ & - & \multirow{2}{*}{$29.8-55.0 * 10^{3}$} \\
\hline & $\mathrm{P}$ & $37.6 * 10^{3}$ & $82.5 * 10^{3}$ & $79.3 * 10^{3}$ & $89.2 * 10^{3}$ & $71.1 * 10^{3}$ & \\
\hline \multirow{2}{*}{$\mathrm{Cd}$} & WB & 0.70 & 0.70 & 0.71 & 0.70 & - & \multirow{2}{*}{$<0.12-3.10$} \\
\hline & $\mathrm{P}$ & 0.66 & 0.75 & 0.84 & 0.64 & 0.65 & \\
\hline \multirow{2}{*}{ Co } & WB & 0.86 & 0.85 & 0.83 & 0.84 & - & \multirow{2}{*}{$<0.02-7.56$} \\
\hline & $\mathrm{P}$ & 0.53 & 1.05 & 0.86 & 1.00 & 0.69 & \\
\hline \multirow{2}{*}{$\mathrm{Cr}$} & WB & - & 0.89 & - & 0.41 & - & \multirow{2}{*}{$1.52-84.9$} \\
\hline & $\mathrm{P}$ & 5.02 & 5.96 & 4.62 & 6.10 & 5.67 & \\
\hline \multirow{2}{*}{$\mathrm{Cu}$} & WB & 717 & 668 & 669 & 779 & - & \multirow{2}{*}{$0.53-1.40 * 10^{3}$} \\
\hline & $\mathrm{P}$ & 471 & 645 & 652 & 851 & 552 & \\
\hline \multirow{2}{*}{$\mathrm{Fe}$} & WB & $457 * 10^{3}$ & $369 * 10^{3}$ & $147 * 10^{3}$ & $380 * 10^{3}$ & - & \multirow{2}{*}{$520-1140 * 10^{3}$} \\
\hline & $\mathrm{P}$ & $1.31 * 10^{3}$ & $3.56 * 10^{3}$ & $2.09 * 10^{3}$ & $1.63 * 10^{3}$ & $1.41 * 10^{3}$ & \\
\hline \multirow{2}{*}{ K } & WB & $171 * 10^{3}$ & $216 * 10^{3}$ & $139 * 10^{3}$ & $216 * 10^{3}$ & - & \multirow{2}{*}{$131-197 * 10^{3}$} \\
\hline & $\mathrm{P}$ & $142 * 10^{3}$ & $305 * 10^{3}$ & $157 * 10^{3}$ & $290 * 10^{3}$ & $157 * 10^{3}$ & \\
\hline \multirow{2}{*}{$\mathrm{Mg}$} & WB & $3580 * 10^{3}$ & $3210 * 10^{3}$ & $2490 * 10^{3}$ & $3530 * 10^{3}$ & - & \multirow{2}{*}{-} \\
\hline & $\mathrm{P}$ & $12.3 * 10^{3}$ & $22.5 * 10^{3}$ & $18.7 * 10^{3}$ & $22.6 * 10^{3}$ & $15.9 * 10^{3}$ & \\
\hline \multirow{2}{*}{ Mn } & WB & 8.12 & 3.21 & 2.68 & 5.37 & - & \multirow{2}{*}{$67-151$} \\
\hline & $\mathrm{P}$ & 3.45 & 4.98 & 4.65 & 4.33 & 3.70 & \\
\hline \multirow{2}{*}{ Mo } & WB & 1.54 & 1.19 & 1.09 & 1.25 & - & $1.27-22.8$ \\
\hline & $\mathrm{P}$ & 15.2 & 10.6 & 7.98 & 9.17 & 8.07 & $1.21-2<.0$ \\
\hline $\mathrm{Ni}$ & WB & 0.72 & 0.85 & 0.80 & 0.84 & - & $<0.38-25.7$ \\
\hline $1 \sqrt{1}$ & $\mathrm{P}$ & 2.54 & 16.94 & 8.20 & 5.34 & 4.10 & $<0.50-25.1$ \\
\hline $\mathrm{Pb}$ & WB & 1.35 & 2.47 & 1.24 & 1.48 & - & $<0.02-4.52$ \\
\hline & $\mathrm{P}$ & 0.04 & 0.14 & $<0.02$ & $<0.02$ & $<0.02$ & \\
\hline $\mathrm{Rb}$ & WB & 63.0 & 126 & 55.0 & 127 & - & $52-149$ \\
\hline $\mathrm{KJ}$ & $\mathrm{P}$ & 37.1 & 102 & 37.3 & 94.7 & 39.8 & $52-14 y$ \\
\hline $\mathrm{Se}$ & WB & 476 & 330 & 530 & 420 & - & $520-2260$ \\
\hline Se & $\mathrm{P}$ & 513 & 701 & 607 & 793 & 840 & $320-2 \angle 00$ \\
\hline $\mathrm{Sr}$ & WB & 61 & 67 & 126 & 85 & - & $25-70$ \\
\hline & $\mathrm{P}$ & 59.8 & 108 & 152 & 140 & 145 & $20-10$ \\
\hline $\mathrm{V}$ & WB & 0.88 & 0.85 & 0.89 & 0.88 & - & $<0.05-1.30$ \\
\hline & $\mathrm{P}$ & 1.66 & 3.62 & 5.77 & 4.58 & 4.61 & \\
\hline $7 \mathrm{n}$ & WB & 2500 & 1840 & 1360 & 2340 & - & $2730-4570$ \\
\hline & $\mathrm{P}$ & 385 & 898 & 686 & 937 & 473 & $2750-450$ \\
\hline
\end{tabular}

animals showed alterations in the lung with hyperplastic lung lymph nodes and alveolar oedema and emphysema. In the bronchia of the animals $\mathrm{Pv} 01,03$, and 05, both, inflamed areas and nematodes, were present. One animal ( $\mathrm{Pv}$ 02) showed a multifocal purulent bronchopneumonia without parasitic burden. The lungs of seal Pv 04 were not collabated and contained a stiff edem fluid. In two animals (Pv 01, 02), only little thymic tissue was found. 
TABle 3: Heavy metal concentrations in liver, kidney, and muscle samples [ $\mathrm{mg} \mathrm{kg}^{-1}$ w.w.] samples.

\begin{tabular}{|c|c|c|c|c|c|c|}
\hline & & Pv 01 & Pv 02 & Pv 03 & Pv 04 & Pv 05 \\
\hline \multirow{3}{*}{ As } & Liver & 0.065 & 0.091 & 0.068 & 0.004 & 0.111 \\
\hline & Kidney & 0.064 & 0.085 & 0.062 & 0.068 & 0.087 \\
\hline & Muscle & 0.044 & 0.058 & 0.005 & 0.064 & 0.053 \\
\hline \multirow{3}{*}{$\mathrm{Cd}$} & Liver & 0.021 & 0.004 & $<0.002$ & 0.005 & 0.010 \\
\hline & Kidney & 0.114 & 0.037 & 0.043 & 0.038 & 0.054 \\
\hline & Muscle & $<0.002$ & $<0.002$ & $<0.002$ & $<0.002$ & $<0.002$ \\
\hline \multirow{3}{*}{$\mathrm{Hg}$} & Liver & 0.009 & 0.023 & 0.013 & 0.017 & 0.023 \\
\hline & Kidney & 0.040 & 0.025 & 0.003 & 0.014 & 0.031 \\
\hline & Muscle & 0.066 & 0.038 & 0.006 & 0.024 & 0.041 \\
\hline \multirow{3}{*}{$\mathrm{Pb}$} & Liver & $<0.0001$ & $<0.0001$ & 0.018 & $<0.0001$ & $<0.0001$ \\
\hline & Kidney & $<0.0001$ & $<0.0001$ & $<0.0001$ & $<0.0001$ & $<0.0001$ \\
\hline & Muscle & 0.004 & $<0.0001$ & 0.006 & $<0.0001$ & $<0.0001$ \\
\hline
\end{tabular}

3.2. Health Parameters in Blood Samples. Serum electrophoresis showed in all five animals high amounts of the total protein concentrations compared to results in free-living seals (See supplementary materials available at doi:10.5402/2012/106259, Table S1) [28, 29]. Compared to free-living harbor seals of the Elbe estuary, the albumin-toglobulin ratios of all five animals were lower [12], indicating higher amount of globulins in relation to albumin in the sick animals than in clinically healthy seals. The concentrations of the acute phase protein CRP were high or in the upper range compared to reference date described for harbor seals [30]. The Hp concentrations were distinctly elevated for four of five seals ( $\mathrm{Pv} 01,03,04,05)$ compared to the reference range of harbor seals [19]. The Tf concentrations were elevated for all five seals and the CDT ratio for Pv 01 compared to published reference ranges determined for wildlife harbor seals of the German North Sea [22]. The general higher levels of acute phase proteins measured in this study support the necropsy findings of inflammation, even if individually variations were found (Table S1).

Clinical chemistry revealed elevated values of AST and ALT in the serum of all five animals compared to reference values for harbor seals [28]. Both enzymes in seals are mainly produced by liver and muscle [31]. In conjunction with the pathological findings, the data suggest a possible linkage to liver damage in these studied animals. The values of the stress-related hormone cortisol were three to five times higher in four of five animals than the reference values published for harbor seals in the CRC Handbook of Marine Mammal Medicine [32] and compared to a study on Alaskan harbor seals [33]. These results can be explained by the disease status as well as nutritional and environmental stress of the animals. The thyroid data showed similar results for all five animals (Table S1). However, the T3 and T4 values are lower compared to mean and minimal values identified by Oki and Atkinson [33]. Although hypothyroidism could not be confirmed, as thyroid-stimulating hormone (TSH) was not quantified, the thyroid profiles of all five seals suggest reduced thyroid activities. Reduced thyroid functionality is also supported by considering that all subjects studied were seals younger than a year and in very bad health.
3.3. Elements in Whole Blood and Plasma. Addition to whole blood data concentrations in plasma samples was published for the first time in this study. Either plasma data to compare the results are not available for seals of this area. In the wholeblood samples, the concentrations of $\mathrm{Cr}, \mathrm{Fe}, \mathrm{Mn}$, and $\mathrm{Zn}$ were significantly lower than the range measured in freeliving seals of the German and Danish Wadden Sea (Table 2) [3]. As these elements are essential for mammals, the results reflect the malnutrition of the seals. Toxic metals were not significantly elevated (Table 2). Most of the elements showed no significant differences compared to our previous study on seals of the Wadden Sea [3]. Compared to animals of the Elbe estuary, many essential as well as toxic elements showed lower concentrations, possibly due to differences in location and feeding habitats as well as malnutrition and possible liver lesions [12].

3.4. Metal Hypersensitivities. The non- and PWM-stimulated lymphocyte proliferations were within the range measured for seals in the Wadden Sea (Table S2) [25]. All metalspecific SI values were in the normal range $>0.1$ and $<3$ (Table S2). Nevertheless, both Helgoland seals showed a possible metal-specific hypersensitivity with $\mathrm{SI} \geq 2$, seal $\mathrm{Pv}$ 01 to $\mathrm{Cr}, \mathrm{Mo}$, and $\mathrm{Pb}$ (multiple reactivity) and seal $\mathrm{Pv} 02$ to $\mathrm{Ni}$ (single reactivity). Interestingly, comparing the animals of this study, Pv 01 had the highest Mo and Pv 02 the highest Ni concentration in plasma (Table 2).

3.5. Metal Concentrations in Liver, Kidney, and Muscle Tissue. All concentrations were below toxic thresholds (Table 3) [34]. In particular, the $\mathrm{Cd}$ concentrations in muscle as well as the $\mathrm{Pb}$ levels in all three sample types were very low or below the detection limit. An acute intoxication of the seals investigated from heavy metals can be excluded. Unfortunately, metal concentrations in tissues of harbor seals of the German North Sea have not been reported in the literature in the last years. However, compared to studies of the seventies, a clear trend is remarkable. While the concentrations of $\mathrm{Cd}$ remained in the same low range, the $\mathrm{Pb}$ and $\mathrm{Hg}$ values decreased significantly $[35,36]$. 
TABLE 4: Chlorinated pesticides and PCBs in plasma in $\mathrm{ng} \mathrm{L}^{-1}$.

\begin{tabular}{|c|c|c|c|c|c|}
\hline & Pv 01 & Pv 02 & Pv 03 & Pv 04 & Pv 05 \\
\hline НCB & 227 & 82 & 49 & 66 & 50 \\
\hline Beta-HCH & 74 & 23 & 42 & 14 & 21 \\
\hline Gamma-HCH & 17 & nd & $<10$ & nd & nd \\
\hline Delta-HCH & nd & nd & nd & nd & nd \\
\hline Heptachlor & nd & nd & 26 & nd & nd \\
\hline Aldrin & nd & nd & 45 & nd & 20 \\
\hline $\begin{array}{l}\text { Heptachlor } \\
\text { epoxide }\end{array}$ & 437 & 115 & 404 & 274 & 288 \\
\hline $\begin{array}{l}\text { Trans- } \\
\text { Chlordane }\end{array}$ & 61 & 11 & 72 & $<10$ & 23 \\
\hline cis-Chlordane & nd & 21 & 77 & 37 & 69 \\
\hline Dieldrin & 329 & 583 & 500 & 191 & 237 \\
\hline Endrin & nd & nd & nd & nd & nd \\
\hline Endosulfan & 76 & 15 & 25 & nd & 13 \\
\hline $2,4^{\prime}-\mathrm{DDE}$ & nd & nd & nd & 153 & nd \\
\hline $4,4^{\prime}-\mathrm{DDE}$ & 6.050 & 9.940 & 9.880 & 8.320 & 12.000 \\
\hline $2,4^{\prime}-\mathrm{DDT}$ & nd & 210 & 350 & 92 & 223 \\
\hline $4,4^{\prime}-\mathrm{DDT}$ & 477 & 798 & 730 & 844 & 876 \\
\hline Methoxychlor & 705 & 1.200 & - & 992 & 1.010 \\
\hline PCB 28 & 522 & - & 294 & 166 & 541 \\
\hline PCB 37 & nd & nd & 10 & nd & nd \\
\hline PCB 52 & 785 & 399 & 207 & 121 & 1.210 \\
\hline PCB 77 & 404 & 214 & 357 & 68 & 505 \\
\hline PCB 81 & nd & 91 & nd & nd & nd \\
\hline PCB 87 & 2.520 & 2.170 & 1.320 & 360 & 2.160 \\
\hline PCB 99 & 1.400 & 1.200 & 731 & 199 & 1.200 \\
\hline PCB 101 & 5.160 & 4.450 & 2.700 & 738 & 4.440 \\
\hline PCB 105 & 312 & 37 & 79 & 28 & 109 \\
\hline PCB 114 & nd & nd & nd & nd & nd \\
\hline PCB 118 & 207 & 193 & 388 & 161 & 199 \\
\hline PCB 123 & nd & nd & nd & nd & nd \\
\hline PCB 126 & nd & nd & nd & nd & nd \\
\hline PCB 128 & 809 & 659 & 862 & 459 & 1.260 \\
\hline PCB 138 & 5.330 & 4.630 & 5.560 & 2.470 & 9.140 \\
\hline PCB 153 & 17.400 & 12.600 & 15.400 & 5.360 & 26.310 \\
\hline PCB 156 & 98 & 131 & 110 & 40 & 129 \\
\hline PCB 157 & 30 & 30 & 34 & 13 & 37 \\
\hline PCB 158 & 46 & 47 & 53 & 21 & 58 \\
\hline PCB 167 & 19 & 19 & 22 & $<10$ & 24 \\
\hline PCB 168 & 14 & 14 & 16 & $<10$ & 17 \\
\hline PCB 169 & nd & nd & nd & nd & nd \\
\hline PCB 170 & 815 & 1.090 & 787 & 200 & 1.440 \\
\hline PCB 180 & 3.930 & 3.380 & 2.060 & 561 & 3.380 \\
\hline PCB 183 & 266 & 315 & 250 & 86 & 460 \\
\hline PCB 189 & 11 & 15 & 11 & $<10$ & 16 \\
\hline PCB 194 & 82 & 118 & 79 & 16 & 130 \\
\hline
\end{tabular}

3.6. Chlorinated Pesticides and PCBs in Plasma. Plasma concentrations of chlorinated pesticides including metabolites

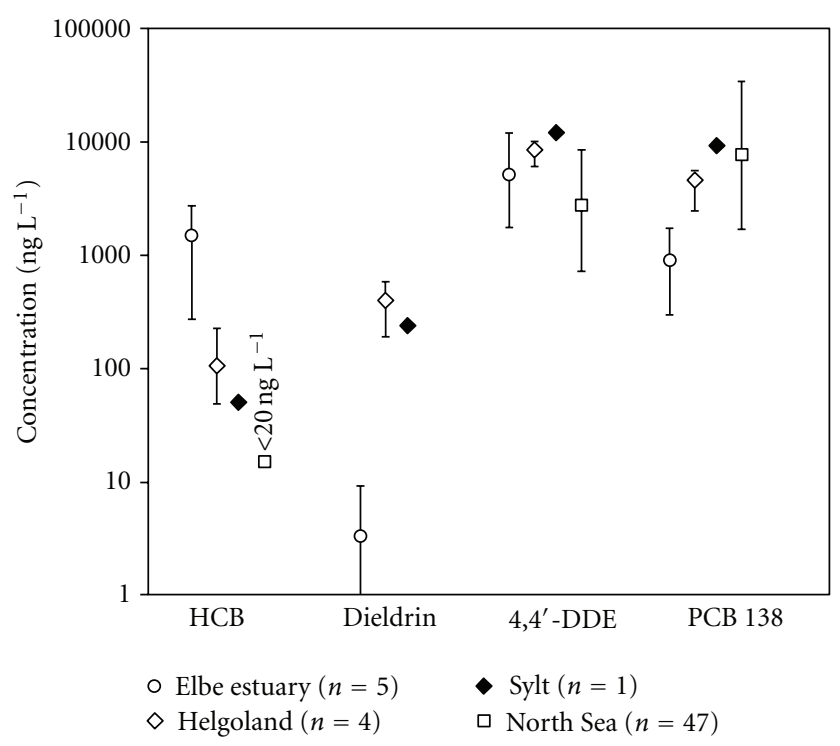

Figure 2: Comparison of blood concentrations of selected organic contaminants with other studies. Means or medians (North Sea) and minimum and maximum concentrations. Number of investigated seals given in parentheses. Data for seals from the Elbe estuary taken from Kakuschke et al. [12], for seals from the North Sea from Weijs et al. [38].

and PCBs for the investigated diseased seals from Helgoland $(\mathrm{Pv} 01-\mathrm{Pv} 04)$ and Sylt $(\mathrm{Pv} 05)$ are given in Table 4. The mean currents in the German Bight transport water masses northwards along the coastline [37], carrying with them inputs from major estuaries, for example, the Rhine, Weser, or Elbe estuaries. Thus, waters around Helgoland can partly be influenced by these riverine inputs as well as the region of Sylt to a lesser extent.

In the comparison with other studies (Figure 2), hexachlorobenzene $(\mathrm{HCB})$ concentrations span a range of three magnitudes. Plasma concentrations of diseased seals of Helgoland and Sylt were lower than in animals living in the Elbe estuary [12] but were higher than serum concentrations in seals of the North Sea [38]. In particular, the Helgoland seals of this study may be influenced by the Elbe plume.

DDT and metabolite concentrations $\left(4,4^{\prime}\right.$-DDE shown in Figure 2) were similar in all three studies. PCBs (PCB 138 shown in Figure 2) for diseased seals were in the same range as in the North Sea study, but slightly elevated compared to seals from the Elbe estuary. Interestingly, dieldrin and other cyclodiene insecticides and metabolites (endosulfan, chlordane, and heptachlor epoxide) showed higher plasma concentrations in the diseased seals of this study compared to animals of the Elbe estuary.

\section{Conclusion}

Although harbor and gray seals are tourist attractions of the islands Helgoland and Sylt, little is known about these local seal groups. This multiparameter investigation provides a first combined data set on health parameters and 
contaminant burdens of five severely ill, juvenile harbor seals from Helgoland and Sylt, which were shot for animal welfare reasons. As expected, the results of pathology and blood investigations support the bad prognosis of survival made in the field. Although the levels of organic contaminants seem to be influenced by the Elbe plume, the concentrations of metal pollutants indicate similar or lower body burdens compared to former studies. However, further investigations are necessary to evaluate the results, and routinely investigations of these seal groups should be performed.

\section{Acknowledgments}

The authors would like to thank all colleagues at the Helmholtz-Zentrum Geesthacht (HZG) and at the Research and Technology Centre (FTZ) in Büsum, the Seal Station Friedrichskoog, the helicopter crew as well as the seal rangers along the North Sea coast for their cooperation and their support in particular Mr. Blädel from Helgoland and Mr. Dethlefs from Sylt.

\section{References}

[1] V. N. de Jonge, M. Elliott, and V. S. Brauer, "Marine monitoring: Its shortcomings and mismatch with the $\mathrm{EU}$ Water Framework Directive's objectives," Marine Pollution Bulletin, vol. 53, no. 1, pp. 5-19, 2006.

[2] S. Fahrenholtz, S. Griesel, D. Pröfrock, and A. Kakuschke, "Essential and non-essential elements in tissues of harbour porpoises (Phocoena phocoena) stranded on the coasts of the North and Baltic Seas between 2004-2006," Journal of Environmental Monitoring, vol. 11, no. 5, pp. 1107-1113, 2009.

[3] S. Griesel, A. Kakuschke, U. Siebert, and A. Prange, "Trace element concentrations in blood of harbor seals (Phoca vitulina) from the Wadden Sea," Science of the Total Environment, vol. 392, no. 2-3, pp. 313-323, 2008.

[4] A. Kakuschke and A. Prange, "The influence of metal pollution on the immune system - a potential stressor for marine mammals in the North Sea," International Journal of Comparative Psychology, vol. 20, pp. 179-193, 2007.

[5] R. J. Law, P. Bersuder, L. K. Mead, and P. D. Jepson, "PFOS and PFOA in the livers of harbour porpoises (Phocoena phocoena) stranded or bycaught around the UK," Marine Pollution Bulletin, vol. 56, no. 4, pp. 792-797, 2008.

[6] J. Mi, A. Orbea, N. Syme, M. Ahmed, M. P. Cajaraville, and S. Cristobal, "Peroxisomal proteomics, a new tool for risk assessment of peroxisome proliferating pollutants in the marine environment," Proteomics, vol. 5, no. 15, pp. 3954$3965,2005$.

[7] S. Mössner and K. Ballschmiter, "Marine mammals as global pollution indicators for organochlorines," Chemosphere, vol. 34, no. 5-7, pp. 1285-1296, 1997.

[8] The Trilateral Wadden Sea Cooperation, The Trilateral Monitoring and Assessment Program (TMAP). Wadden Sea Plan 2010, Common Wadden Sea Secretariat, Wilhelmshaven, Germany, 2010.

[9] P. M. Bennett, P. D. Jepson, R. J. Law et al., "Exposure to heavy metals and infectious disease mortality in harbour porpoises from England and Wales," Environmental Pollution, vol. 112, no. 1, pp. 33-40, 2001.
[10] P. D. Jepson, P. M. Bennett, C. R. Allchin et al., "Investigating potential associations between chronic exposure to polychlorinated biphenyls and infectious disease mortality in harbour porpoises from England and Wales," Science of the Total Environment, vol. 243-244, pp. 339-348, 1999.

[11] U. Siebert, C. Joiris, L. Holsbeek et al., "Potential relation between mercury concentrations and necropsy findings in cetaceans from German waters of the North and Baltic Seas," Marine Pollution Bulletin, vol. 38, no. 4, pp. 285-295, 1999.

[12] A. Kakuschke, E. Valentine-Thon, S. Griesel et al., "First health and pollution study on harbor seals (Phoca vitulina) living in the German Elbe estuary," Marine Pollution Bulletin, vol. 60, no. 11, pp. 2079-2086, 2010.

[13] K. Abt, Meeressäugerfunde an den Küsten Schleswig-Holsteins 2010, Nationalparkverwaltung im Landesbetrieb für Küstenschutz, Nationalpark und Meeresschutz SchleswigHolstein, Kiel, Germany, 2011.

[14] K. Abt, Robbenzählungen im schleswig-holsteinischen Wattenmeer 2010, Nationalparkverwaltung im Landesbetrieb für Küstenschutz, Nationalpark und Meeresschutz SchleswigHolstein, Kiel, Germany, 2011.

[15] K. Abt and J. Engler, "Rapid increase of the grey seal (Halichoerus grypus) breeding stock at Helgoland," Helgoland Marine Research, vol. 63, no. 2, pp. 177-180, 2009.

[16] D. Adelung and G. Müller, Forschungsverbund MINOSplusWeiterführende Arbeiten an Seevögeln und Meeressäugern zur Bewertung von Offshore-Windkraftanlagen, Teilvorhaben TP6 — "Seehunde in See"-Untersuchungen zur räumlichen und zeitlichen Nutzung der Nordsee durch Seehunde im Zusammenhang mit der Entwicklung von Offshore-Windenergieanlagen, Ministeriums für Umwelt, Naturschutz und Reaktorsicherheit, Universität Kiel, Germany, 2008.

[17] U. Siebert, P. Wohlsein, K. Lehnert, and W. Baumgärtner, "Pathological Findings in Harbour Seals (Phoca vitulina): 1996-2005," Journal of Comparative Pathology, vol. 137, no. 1, pp. 47-58, 2007.

[18] U. Siebert, H. Seibel, I. Hasselmeier et al., Untersuchungen zum Gesundheitszustand von Robben in Schleswig-Holstein im Jahr 2009, Bericht an das Ministerium für Umwelt, Natur und Landwirtschaft des Landes Schleswig-Holstein und an das Landesamt für den Nationalpark Schleswig-Holsteinisches Wattenmeer, Kiel, Germany, 2009.

[19] A. Kakuschke, H. B. Erbsloeh, S. Griesel, and A. Prange, "Acute phase protein haptoglobin in blood plasma samples of harbour seals (Phoca vitulina) of the Wadden Sea and of the isle Helgoland," Comparative Biochemistry and Physiology B, vol. 155, no. 1, pp. 67-71, 2010.

[20] M. Grebe, Isolierung und Charakterisierung von TransferrinGlykoformen aus Blutproben von Seehunden mittels multidimensionaler chromatographischer Verfahren und molekülund element-spezifischer massenspektrometrischer Detektion, Ph.D. thesis, Universität Hamburg, Fakultät für Mathematik, Informatik und Naturwissenschaften, Hamburg, Germany, 2011.

[21] M. Grebe, D. Pröfrock, A. Kakuschke, J. A. C. Broekaert, and A. Prange, "Metallomics approach for the identification of the iron transport protein transferrin in the blood of harbour seals (Phoca vitulina)," Metallomics, vol. 2, no. 10, pp. 683-693, 2010.

[22] M. Grebe, D. Pröfrock, A. Kakuschke, J. A. C. Broekaert, and A. Prange, "Absolute quantification of transferrin in blood samples of harbour seals using HPLC-ICP-MS," Metallomics, vol. 3, no. 2, pp. 176-185, 2011. 
[23] H. Rosenfeld, S. Lassen, and A. Prange, "Characterization of haptoglobin in the blood plasma of harbor seals (Phoca vitulina)," Journal of Proteome Research, vol. 8, no. 6, pp. 29232932, 2009.

[24] A. Wargel, Entwicklung eines Zellkulturmodells zur Untersuchung des Schadstoffeinflusses auf Seehunde (Phoca vitulina), Ph.D. thesis, Leuphana Universität Lüneburg, Institut für Umweltchemie, Lüneburg, Germany, 2011.

[25] A. Kakuschke, E. Valentine-Thon, S. Griesel, S. Fonfara, U. Siebert, and A. Prange, "Immunological impact of metals in harbor seals (Phoca vitulina) of the North Sea," Environmental Science and Technology, vol. 39, no. 19, pp. 7568-7575, 2005.

[26] A. Kakuschke, E. Valentine-Thon, S. Fonfara et al., "Metalinduced impairment of the cellular immunity of newborn harbor seals (Phoca vitulina)," Archives of Environmental Contamination and Toxicology, vol. 55, no. 1, pp. 129-136, 2008.

[27] A. Kakuschke, E. Valentine-Thon, S. Griesel et al., "Blood metal levels and metal-influenced immune functions of harbour seals in captivity," Marine Pollution Bulletin, vol. 56, no. 4, pp. 764-769, 2008.

[28] M. E. Lander, J. T. Harvey, and F. M. D. Gulland, "Hematology and serum chemistry comparisons between free-ranging and rehabilitated harbor seal (Phoca vitulina richardsi) pups," Journal of Wildlife Diseases, vol. 39, no. 3, pp. 600-609, 2003.

[29] L. C. McConnell and R. W. Vaughan, "Some blood values in captivity and free-living common seals (Phoca vitulina)," Aquatic Mammals, vol. 10, pp. 9-13, 1983.

[30] A. Kakuschke, D. Pröfrock, and A. Prange, "C-reactive protein in blood plasma and serum samples of harbour seals (Phoca vitulina)," submitted.

[31] D. A. Fauquier, J. A. K. Mazet, F. M. D. Gulland, T. R. Spraker, and M. M. Christopher, "Distribution of tissue enzymes in three species of pinnipeds," Journal of Zoo and Wildlife Medicine, vol. 39, no. 1, pp. 1-5, 2008.

[32] D. J. S. Aubin, "Endocrinology," in Handbook of Marine Mammal Medicine, L. A. Dierauf and F. M. D. Gulland, Eds., pp. 165-192, CRC Press, Boca Raton, Fla, USA, 2001.

[33] C. Oki and S. Atkinson, "Diurnal patterns of cortisol and thyroid hormones in the Harbor seal (Phoca vitulina) during summer and winter seasons," General and Comparative Endocrinology, vol. 136, no. 2, pp. 289-297, 2004.

[34] AMAP, "Heavy metals. Arctic monitoring and assessment program," in AMAP Assessment Report: Arctic Pollution Issues, chapter 7, AMAP, Oslo, Norway, 1998.

[35] H. E. Drescher, U. Harms, and E. Huschenbeth, "Organochlorines and heavy-metals in harbor seal Phoca vitulina from German North Sea Coast," Marine Biology, vol. 41, pp. 99-106, 1977.

[36] U. Harms, H. E. Drescher, and E. Huschenbeth, "Further data on heavy metals and organochlorines in marine mammals from German Coastal Waters," Meeresforschung-Reports on Marine Research, vol. 26, pp. 153-161, 1978.

[37] OSPAR, Quality Status Report 2000, OSPAR Commission, London, UK, 2000.

[38] L. Weijs, K. Das, U. Siebert et al., "Concentrations of chlorinated and brominated contaminants and their metabolites in serum of harbour seals and harbour porpoises," Environment International, vol. 35, no. 6, pp. 842-850, 2009. 

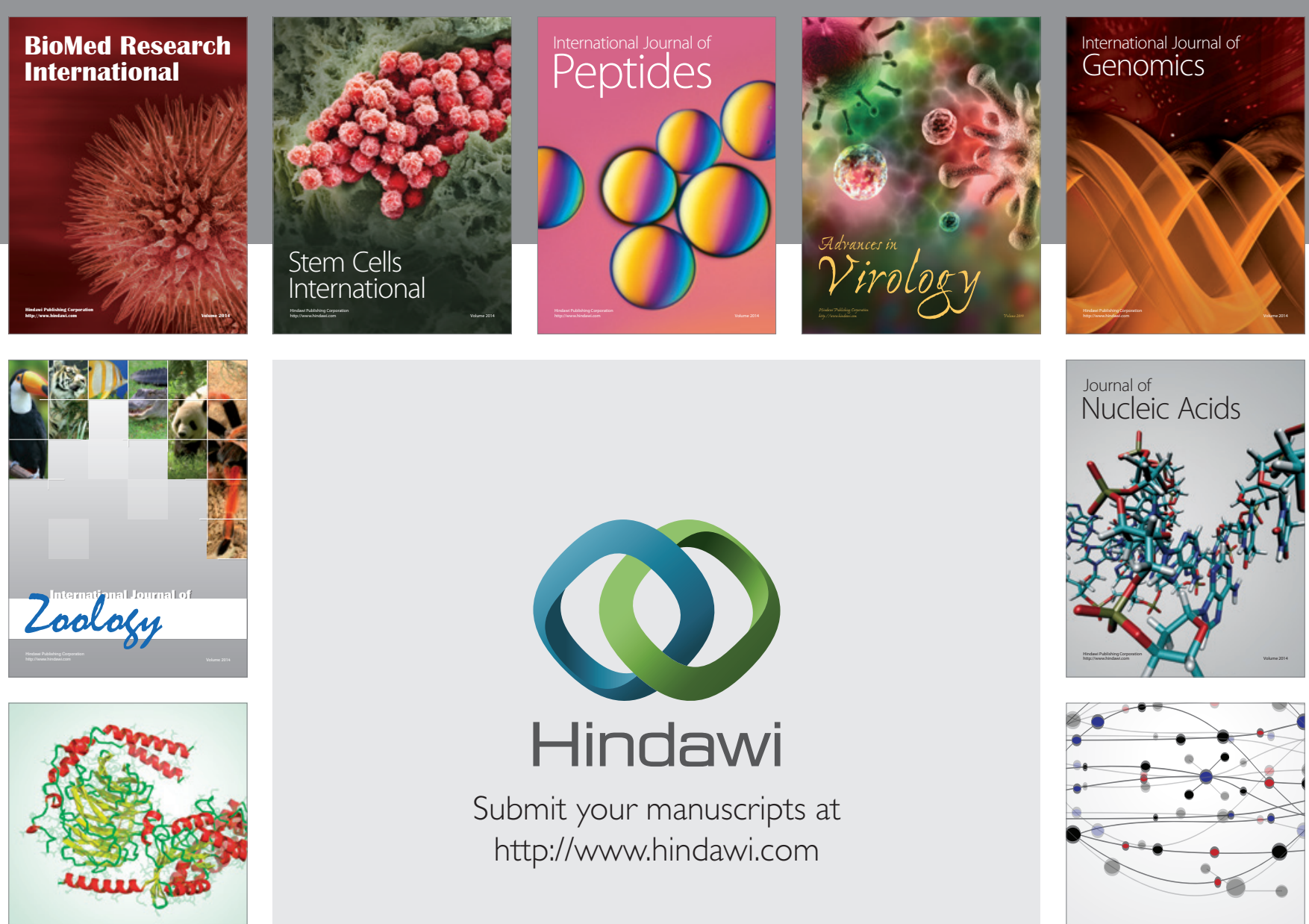

Submit your manuscripts at

http://www.hindawi.com

Signal ${ }^{\text {Jumal }}$ Transduction
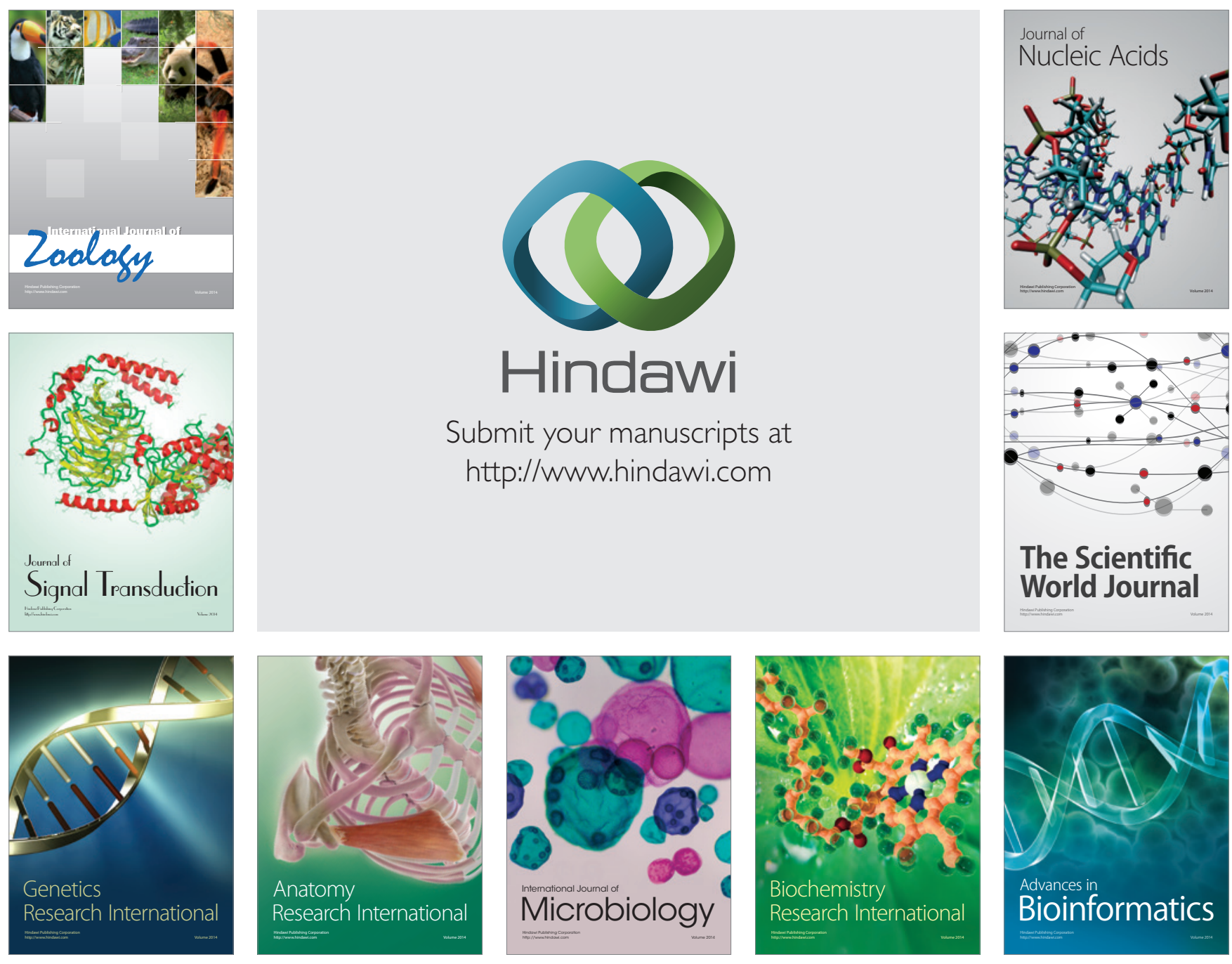

The Scientific World Journal
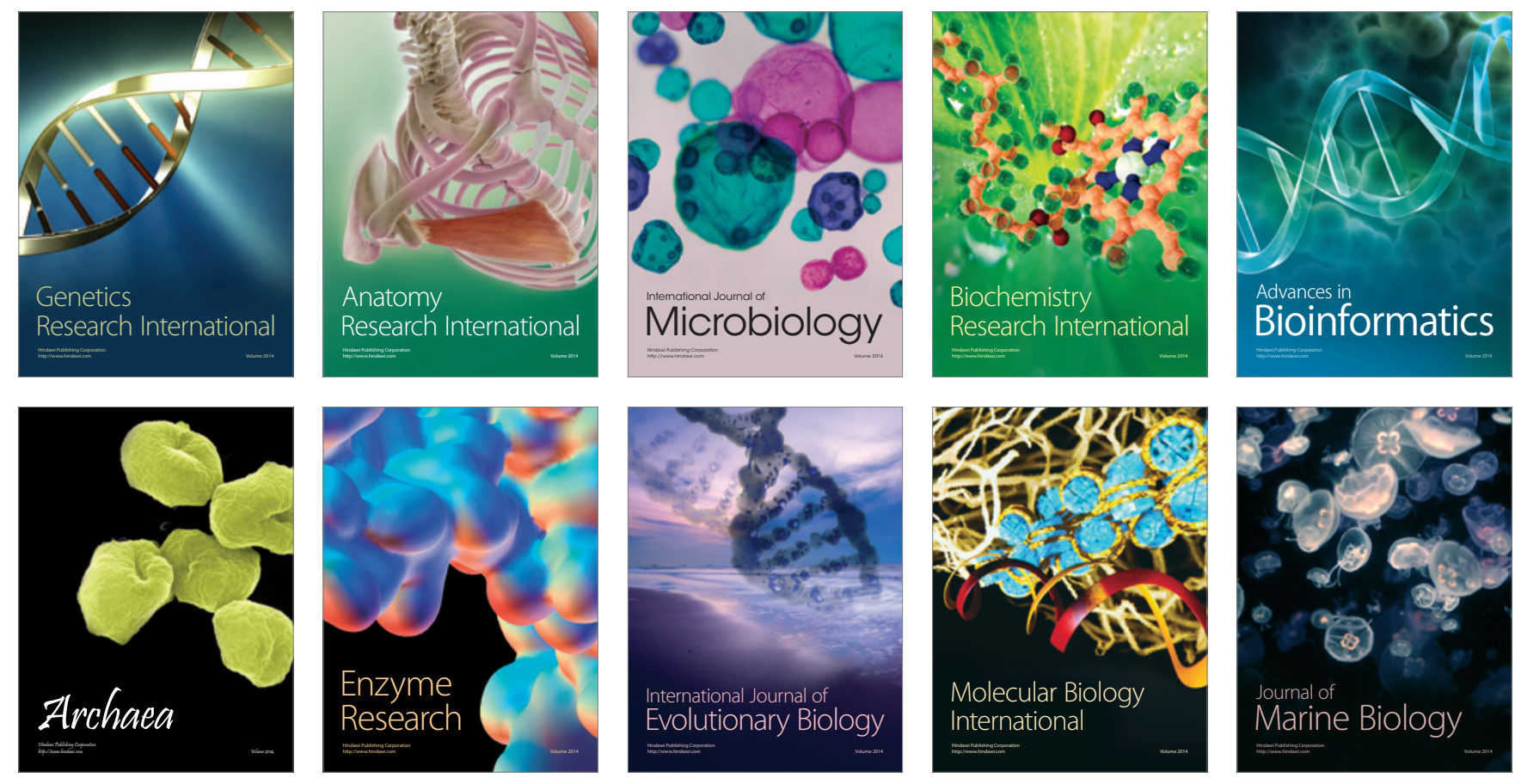